\title{
Analysis of germination in seeds of different geno types of habanero chili pepper (capsicum chinense jacq.) treated with gibberellic acid
}

\begin{abstract}
The objective of this research was to analyze the percentage of germination based on seedlings emergence in ten genotypes of Habanero chili pepper (Capsicum chinense Jacq.) undercontrolled conditions in San Quintin Valley, State of Baja California. Twelve hours prior to planting, the seed was treated with gibberellic acid at $40 \%$ of its concentration, this with the purpose of guaranteeing the germination and seedlings emergence. Sowing was carried out from February $21^{\text {st }}, 2013,2014,2015,2017$ in seed trays of polystyrene with 130 cavities, which were taken to a company dedicated to commercial production of seedlings, the seedlings emergence was registered, with which the germination of seeds was determined for each genotype. The evaluated genotypes were two commercial varieties; Yucatan Jaguar and Jaguar INIFAP, as well as experimental materials: HRA 7-1, HNY 201, HAN 1-30, HRA 1-1, HAN 25, 1-40, HQR 15-3 and 15-1 HUX. The ten genotypes treated with gibberellic acid had good response on germination and seedlings emergence under the conditions of the San Quintin Valley, State of Baja California. Statistically significant differences did not occur and it obtained an average of $98.4 \%$, but $\mathrm{F}_{1}$ and $\mathrm{F}_{2}$ of the Spartacus hybrid seeds without being treated with the acid, had only $46 \%$ of germination, with what can be inferred that the gibberellic acid, under the conditions of San Quintin Valley, Baja California, and with management applied in the system of production of seedlings, it increases significantly the germination of seeds of habanero chili pepper.
\end{abstract}

Keywords: germination, genotypes, seed, gibberellic acid, capsicum chinense Jacq
Volume 5 Issue 3 - 202I

\author{
Aurelia Mendoza-Gómez, ${ }^{1,4}$ Teresa de Jesús \\ Velázquez-Alcaraz, ${ }^{2}$ Carlos Alfonso López- \\ Orona, ${ }^{2}$ Felipe Ayala-Tafoya, ${ }^{2}$ Tomás Díaz- \\ Valdez, ${ }^{2}$ Mario Ernesto Vázquez-Badillo, ${ }^{3}$ \\ Ángel Manuel Suarez-Hernández, ${ }^{4}$ Fidel \\ Núñez-Ramirez \\ 'PhD. Student in Agricultural Sciences, Agronomy Faculty, \\ Autonomous University of Sinaloa (UAS), México \\ ${ }^{2}$ Agronomy Faculty, Autonomous University of Sinaloa (UAS), \\ México \\ Universidad Autónoma Agraria Antonio Narro, México \\ ${ }^{4}$ Faculty of Engineering and Business San Quintín,Autonomous \\ University of Baja California (UABC), México \\ ${ }^{5}$ Institute of Agricultural Sciences, Autonomous University of \\ Baja California (UABC), México
}

\begin{abstract}
Correspondence: Aurelia Mendoza-Gómez, PhD. Student in Agricultural Sciences, Agronomy Faculty, Autonomous University of Sinaloa (UAS), Institute of Agricultural Sciences, Autonomous University of Baja California (UABC), México,

Email aurelia.mendoza@uabc.edu,mxauremza8I@gmail.com
\end{abstract}

Received: June 03, 2021 | Published: June 25, 202।

\section{Introduction}

The habanero chili pepper (Capsicum chinense Jacq.) belongs to the Solanaceae family, includes about 25 species. It has its center of origin in tropical and subtropical regions of America. ${ }^{1}$

One of the main challenges in the production of Habanero chili pepper is to have a good seed germination to get healthy seedlings, vigorous and in good quality at the time of transplantation. The application of hormones plays an important role in the germination, growth and development of the aerial and radical part of the seedlings; there are five types of growth hormones in plants: auxins, cytokinins, gibberellins, abscisic acid and ethylene, in which gibberellins (gibberellic acid) accelerate the germination of the seeds, helping to break the dormancy. Habanero seeds decrease germination after storage periods longer than 100 days, conditioning treatments improve, accelerate and create uniformity in the germination of seeds. ${ }^{2}$ who conducted a study on the conditioning pre-planting to increase germination in habanero pepper using different treatments and among them the gibberellic acid, determined that this increases the germination and emergence of the seeds. Planting was performed in the year 2013, of a commercial hybrid habanero, which was treated with gibberellic acid before sowing and obtained a $99 \%$ germination.
Later in 2014 in the greenhouse of the faculty of engineering and business in San Quintin, the planting of a commercial hybrid seed of habanero and its population F2, the seed was not previously treated with plant growth regulators and the percentage of germination of it was $43 \%$, later in 2015 the planting of the same material and the seed was done and treated with gibberellic acid and was taken to the seedling production area for their development and a $97 \%$ germination was obtained. Capsicum chinense is an important horticultural crop in the diet of the population in many parts of the world; in Mexico, planted in various states, mainly Yucatan, Tabasco, Campeche and Quintana Roo, where yields ranging between 10 and 30 tons are obtained per acre, according to the level of technification used in the growing process. San Quintin Valley is an important agricultural area, more than $90 \%$ of its activities are related to agriculture, since 2013 , around 13 acres of plantings have been established in the region., In the San Quintin Region, in the 70's and 80's, large expanses of open-field crops of chili were produced, later it was replaced by other vegetables and strawberries, currently the plantings of chilies are very scarce, ${ }^{5}$ made an analysis of the productive potential of a hybrid of hab anero chili was carried out, seeded at an experimental level in the region of the San Quintin Valley, and 78 tons per acre was obtained. Currently the cultivation of Habanero pepper is not 
practiced commercially in the San Quintin Valley, Baja California, since the genotypes that adapt to the conditions of the area in question are unknown, either in greenhouse conditions or in open field, with good growth, development and performance compared to what they express in the producing regions of Mexico. The objective of this research was to determine the percentage of germination based on the habanero pepper seedling emergence (Capsicumchinense Jacq.) in protected conditions (greenhouse) in San Quintin Valley, Baja California, as a first stage for the determination of the genotypes that best adapt to the valley conditions in order to make a recommendation of its commercial planting in the region.

\section{Materials and methods}

The seed was treated with gibberellic acid during the years 2014 , 2015 and 2017, the sowing of the genetic material was carried out in polystyrene trays with 130 cavities in the experimental field (greenhouse) facility of the Universidad Autónoma de Baja California, Faculty of Engineering and Business, located in San Quintin Valley $180 \mathrm{~km}$ south of the city of Ensenada, Baja California, with geographic location of $30^{\circ} 33^{\prime} 37^{\prime \prime}$ north latitude and $115^{\circ}$ 56 '33" west longitude, with an altitude of 28 meters and an average annual temperature of $18^{\circ} \mathrm{C}$. Later the trays were transferred to a commercial company (Bajaplants S de RL de CV) that is dedicated to the commercial production of seedlings, to give them the optimal conditions for good seed germination and emergence. In 2013 a commercial hybrid was sown under the same conditions and in 2014 the seed used was the same commercial hybrid and its F2 population, gibberellic acid wasn't used and it's germination was $47 \%$, later in 2017, ten genotypes were planted: two commercial varieties (Yucatan Jaguar and jaguar INIFAP), and eight experimental materials HRA 7-1, HNY 201, HAN 1-30, HRA 1-1, HAN 25, HAN 1-40, HQR 15-3 and HUX 15-1; the two varieties come from the Yucatan Peninsula and the eight experimental lines were generated at the Instituto Nacional de Investigaciones Forestales, Agrícolas y Pecuarias (INIFAP). ${ }^{6}$ The statistical model used was based on the methodology of Steel \& Torrie $^{7}$ for which a completely randomized design with four treatments and four repetitions were used. For this last experiment, the planting was carried out on February $21^{\text {st }}, 2017$ in polystyrene trays with 130 cavities, established in a company dedicated to the commercial production of seedlings, since it has the optimal conditions of temperature and humidity required for germination and the chilies emergence. (Figure $1 \&$ Figure 2), later the emergence of seedlings was registered, on the basis of which seed germination was determined for each genotype. The data was subjected to variance analysis and multiple comparisons of means with the Tukey test with $\alpha \leq 0.05$, using R statistical package.

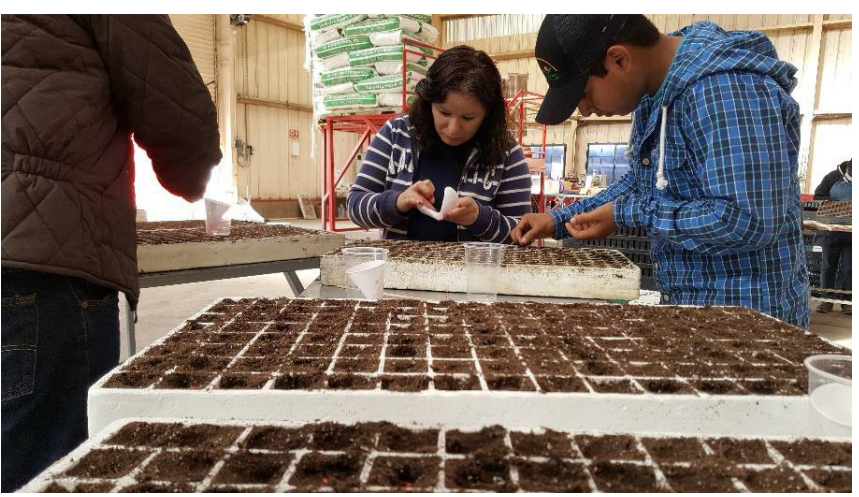

Figure I Sowing of seeds in the trays with I 30 cavities.
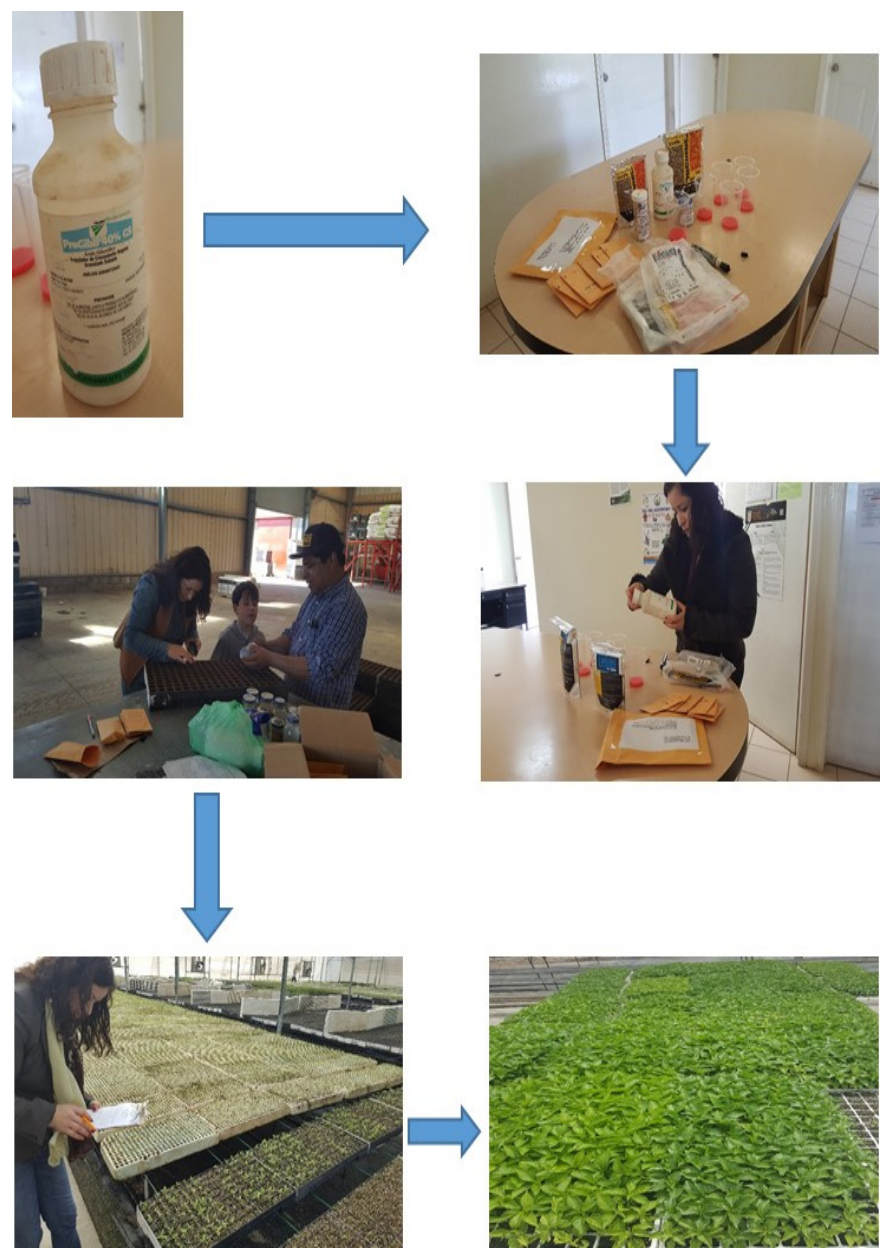

Figure 2 Conditioning, sowing of seeds and seedling development of Habanero chili pepper (Capsicum chinense Jacq.) in Baja Plants, S.A. de C.V. San Quintín, B. C. January, 2017.

\section{Results and discussion}

The emergence of the different genotypes began at 13 days after sowing (das),progress was gradual in each of the materials, and the event ended at 23 (das)without significant statistical differences between treatments (genotypes). A general average of $98.4 \%$ was obtained of the 10 genotypes planted, but the commercial variety Jaguar Yucatán presented $100 \%$ germination and seed emergence (Table 1). In accordance with, ${ }^{8}$ there are different factors, biotic and abiotic, that can affect seed germination and the emergence of seedlings, also excessive humidity significantly affects seed germination in rice cultivation, as well as promotes seed fungi.

The results that are shown in Tables 1-Table 4 indicate that the use of the stimulating hormones in pre-sowing seed is important, three years ago gibberellic acid was applied and an average of $98 \%$ of germination was obtained, while materials planted in 2014 (Table 3 ), where the hormone was not applied, the germination average was $46 \%$. According to, ${ }^{9}$ who carried out a pre-sowing conditioning, as an option to increase the germination of habanero pepper, used abscisic acid and gibberellic acid as germination inducers, and concluded that seed conditioning is optimal if germination and emergence increase. The seeds applied with gibberellic acid increased the speed of germination in comparison with control. 
Table I Percentage of seedlings of different genotypes of Habanero pepper (Capsicumchinense Jacq.) With gibberellic acid treatment. March, 20 I 7

\begin{tabular}{llll}
\hline Treatments & $\begin{array}{l}\text { Seeds } \\
\text { planted }\end{array}$ & $\begin{array}{l}\text { Emerged } \\
\text { seedlings }\end{array}$ & Percentage \\
\hline $\begin{array}{l}\text { Jaguar INIFAP } \\
\text { (commercial variety) }\end{array}$ & 130 & 127 & 97 \\
HRA 7-I & 130 & 128 & 99 \\
HNY 20I & 130 & 127 & 98 \\
HAN I-30 & 130 & 129 & 99 \\
HRA I-I & 130 & 127 & 97 \\
HAN 25 & 130 & 129 & 99 \\
HAN I-40 & 130 & 128 & 98 \\
HQR I5-3 & 130 & 128 & 98 \\
HUX I5-I & 130 & 129 & 99 \\
$\begin{array}{l}\text { Jaguar Yucatán } \\
\text { (commercial variety) }\end{array}$ & 130 & 130 & 100 \\
\hline
\end{tabular}

Data obtained in the seedling production system of San Quintin, B. C. February, 2017

Table 2 Percentage of seedlings emergence in a hybrid Habanero chili (Capsicumchinense Jacq.) with gibberellic acid treatment. March, $20 \mathrm{I} 5$

\begin{tabular}{llll}
\hline Genotypes & Seeds planted & Emerged seedlings & Percentage \% \\
\hline Commercial Hybrid (Spartacus) & 130 & 126 & 96.9 \\
Commercial Hybrid (Spartacus) & 130 & 129 & 99.23 \\
Commercial Hybrid (Spartacus) & 130 & 125 & 96.15 \\
Commercial Hybrid (Spartacus) & 130 & 128 & 98.46 \\
& & & 97.68
\end{tabular}

Data obtained in the seedling production system of San Quintin, B. C. February, 2015

Table 3 Emerged seedlings percentage of a Habanero chili hybrid (Capsicumchinense Jacq.) without gibberellic acid treatment. March 20 I4

\begin{tabular}{llll}
\hline Genotypes & Seeds planted & Emerged seedlings & Percentage \% \\
\hline Commercial Hybrid (Spartacus) & 130 & 59 & 45.38 \\
Commercial Hybrid (Spartacus) & 130 & 61 & 46.9 \\
F $_{2}$ Population (Spartacus) & 130 & 63 & 48.46 \\
F $_{2}$ Population (Spartacus) & 130 & 58 & 44.6 \\
\hline
\end{tabular}

Data obtained in the seedling production system of San Quintin, B. C. February, 20I4

Table 4 Emerged seedlings percentage of a habanero chili hybrid (Capsicumchinense Jacq.) With gibberellic acid treatment. March 20 I 3

\begin{tabular}{llll}
\hline Genotypes & Seeds planted & Emerged seedlings & Percentage \% \\
\hline Commercial Hybrid (Spartacus) & 130 & 129 & 99.23 \\
Commercial Hybrid (Spartacus) & 130 & 130 & 100 \\
Commercial Hybrid (Spartacus) & 130 & 128 & 98.46 \\
Commercial Hybrid (Spartacus) & 130 & 130 & 100 \\
\hline
\end{tabular}

Data obtained in the seedling production system of San Quintin, B. C. February, 2013

The results that are shown in Table $5 \&$ Table 6 indicate that the use of the stimulating hormones in pre-sowing seed is important, three years ago gibberellic acid was applied and an average of 98\% of germination was obtained, while materials planted in 2014, where the hormone was not applied, the germination average was $46.2 \%$. According to, ${ }^{9}$ who carried out a pre-sowing conditioning, as an option to increase the germination of habanero pepper, used abscisic acid and gibberellic acid as germination inducers, and concluded that seed conditioning is optimal if germination and emergence increase. During the years 2013, 2015 and 2017, when the hormone wasapplied to induce germination, in the comparison of means, the groups are homogeneous, thatis, there are not significant differences, however in 2014 whengibberellic acid wasnotapplied, the Germination percentage decreased considerably. 
Table 5 Average germination in seeds of different experimental genotypes of Capsicum chinense Jacq, treated with Gibberelic acid, San Quintín, Baja California, México. 2017

\begin{tabular}{lllll}
\hline Genotypes & Seeds planted & Emerged seedlings & Percentage & Homogeneous groups \\
\hline Jaguar INIFAP & 130 & 127 & 97.7 & $\mathrm{ab}$ \\
HRA 7-I & 130 & 125 & 96 & $\mathrm{~b}$ \\
HNY 20I & 130 & 127 & 97.7 & $\mathrm{ab}$ \\
HAN I-30 & 130 & 129 & 99.2 & $\mathrm{a}$ \\
HRA I-I & 130 & 128 & 98 & $\mathrm{ab}$ \\
HAN 25 & 130 & 128 & 99.5 & $\mathrm{a}$ \\
HAN I-40 & 130 & 128 & 97.7 & $\mathrm{ab}$ \\
HQR I5-3 & 130 & 128 & 98.5 & $\mathrm{ab}$ \\
HUX I5-I & 130 & 128 & 99 & $\mathrm{a}$ \\
Jaguar Yucatán & 130 & 230 & 100 & $\mathrm{a}$ \\
\hline
\end{tabular}

Data obtained in the seedling production system of San Quintin, B. C. March, 2017

Table 6 Average germination in seeds of different experimental genotypes of Capsicum chinense Jacq,treated with Gibberelic acid, San Quintín, Baja California, México. 2017

\begin{tabular}{lllll}
\hline Treatment byYear & Seeds planted & Emerged seedlings & Percentage & Homogeneous groups \\
\hline 2013 & 130 & 129 & 99 & a \\
$2014^{*}$ & 130 & 60 & 46.25 & $\mathrm{~b}$ \\
2015 & 130 & 127 & 97.5 & $\mathrm{a}$ \\
2017 & 130 & 129 & 99.12 & $\mathrm{a}$
\end{tabular}

Data obtained in the seedling production system of San Quintin, B. C. Not treated with Gibberelic acid

Gibberellins are directly involved in the control and promotion of seed germination; gibberellic acid can break seed dormancy and replace the need for environmental stimuli, such as light and temperature. ${ }^{10}$ The percentages of emergence (Figure 3) that do not necessarily imply germination percentages, because this may occur without there being seedling emergence; that is to say, the end of the germination can occur with the exit of the radicle on the seed's testa (seed coat), but the emergence of seedlings is inhibited by the action of biotic factors (fungi, bacteria and plagues) or abiotic factors (high or low temperatures), drought or excessive humidity, etc.), as referred by, ${ }^{8}$ in this investigation the percentages of emergence indicate that all genotypes under study respond satisfactorily to height above sea level and geographical location of the San Quintin Valley, Baja California
(Figure 4), which it is a good beginning for the planting of Habanero peppers. ${ }^{11}$ they conducted an investigation on Gibberelic acid and seed germination of Jaltomata procumbens (Cav.) J. L. Gentry, evaluated six concentrations of gibberellic acid $(0 ; 50 ; 100 ; 150 ; 200$ and 250 $\mathrm{mg} / \mathrm{l})$ and two soaking times (12 and 24 hours), generating a total of 12 treatments, each one was repeated three times, which totaled 36 experimental units and each one with 50 seeds. The treatments were sown in germinating trays, with moss and perlite substrate (1:1), according to the results, treatments of $250 \mathrm{mg} / 1$ of Gibberelic acid induced $87 \%$ of germination, with 1.7 plants germinated per day over a period of 25.5 days, higher than any other treatment. The time of soaking influences seed germination less than the application of Gibberelic acid.

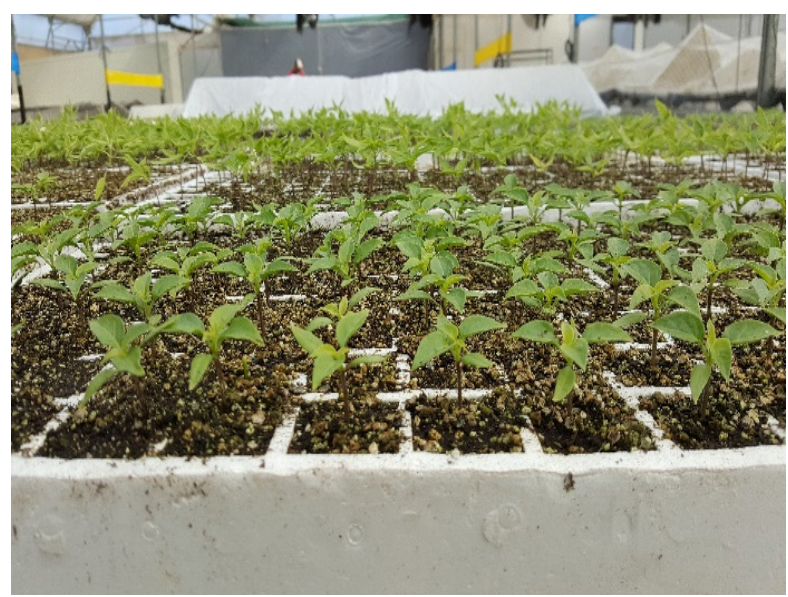

Figure 3 Growth of Habanero pepper seedlings (Capsicumchinense Jacq.) In the commercial production system in San Quintin, B.C.

Citation: Mendoza-Gómez A, Velázquez-Alcaraz TJ, López-Orona CA, et al.Analysis of germination in seeds of different geno types of habanero chili pepper (capsicum chinense jacq.) treated with gibberellic acid. Horticult Int J. 202 I;5(3): I39-143. DOI: 10.15406/hij.2021.05.00220 


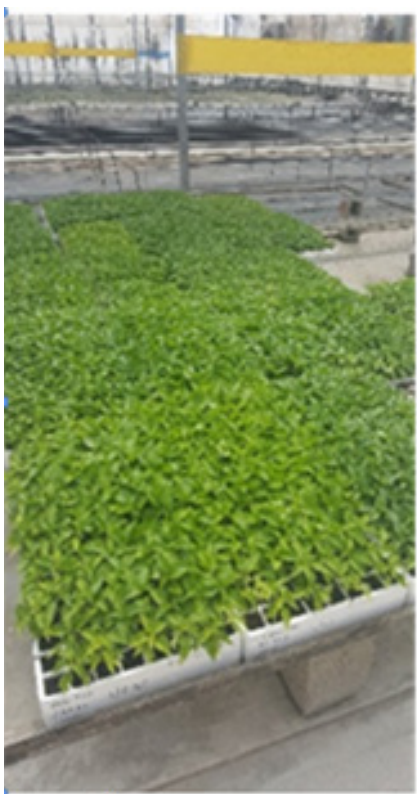

A

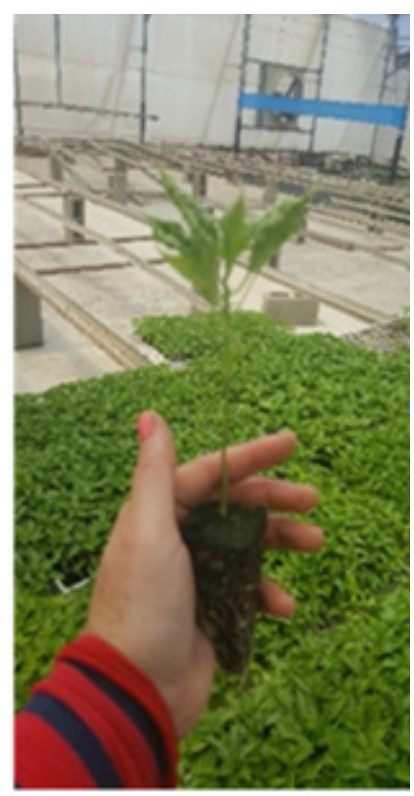

B
Figure 4 (A) General view of trays with Habanero pepper seedlings in the production system and (B) seedling with root ball that allows seeing part of the roots formed.

\section{Conclusion}

The results obtained during the years of evaluation show that with the use of gibberellic acid at a concentration of $40 \%$, the germination of Capsicum chinense seeds is increased by $60 \%$ more than in the seeds where the treatment was not applied, the seeds treated with gibberellic acid responded better to germination, with an average of $98 \%$, while seeds that were not treated with gibberellic acid showed $46 \%$ germination, during the four years of evaluation, in which gibberellic acid was applied as pre-sowing treatment to reduce dormancy in Habanero pepper seeds, the materials had a good response in germination and emergence, with what can be deduced that with the Gibberellic Acid, underconditions of San Quintin Valley, Baja California, and with the applied management in the system of seedling production, the germination of Habanero pepper seeds increased in an important way; the evaluated genotypes can adapt better to these environmental conditions and be promising for commercial purposes. The use of gibberellic acid prior to sowing habanero pepper seeds increases germination by $60 \%$, it is recommended to use at a concentration of $40 \%$ and treat the seed 24 hours before sowing, putting $10 \mathrm{~g}$ of the product in 1 liter of water and immersing the seed, after this time sow the seeds in trays and put sow the seeds in traysand put them in the area seedling production.

\section{Funding}

None.

\section{Acknowledgments}

None.

\section{Conflicts of interest}

The authors have no conflict of interest for this research.

\section{References}

1. Long SJ. Capsicum y cultura: La historia del chilli. 2a edición México. Fondo de cultura Económica. 1998:77-81.

2. Malveira, FR, López R, Silva BW, et al. Morphologic characterization and genetic diversity of Capsicum chinense Jacq. Accessions along the upper Rio Negro - Amazonas. Crop Breeding and Applied Biotechnology. 2008;8:187-194.

3. SEFOA. Secretaria de Fomento Agropecuario Baja California. http:// www.sefoa.gob.mx. (Consultado en Julio de 2014) 2014.

4. SIAP. Cierre de la producción agrícola por cultivo.www.siap.gob.mx. (Consultado enAgosto de2014). 2014.

5. Mendoza, GA, Bazante GI, Ruiz CJ, et al. Análisis de Rendimiento en un Híbrido de Chile Habanero durante tres ciclos de evaluación. Acta Fitogenética. 2016;3:124.

6. Ramírez, MM, Vázquez GE. Potencial de producción del chile habanero (Capsicum chínense), en el sur de Tamaulipas. INIFAP. Campo Experimental Sur de Tamaulipas. 2007.

7. Steel RGD. JH Torrie. Principles and procedures of statistics. Mc. GrawHill, New York. 1980;481.

8. Catalá MDM, Martínez M, Tomas N, et al. Estudio de los factores que afectan la germinación y nacencia en los arrozales del Delta del Ebro. Revista Técnica de Agrícola en Vergel. 2008;288-294.

9. Garruña HRM, Latournerie ML, Santamarina JM, et al. Acondicionamiento pre-siembra: una opción para incrementar la germinación de semillas de chile habanero (Capsicum chinense Jacq.) Agrociencia. 2004;48:413423.

10. Araya E, Gómez L, Hidalgo N, et al. Efecto de la luz y del ácido giberélico sobre la germinación in vitro de Jaul (Alnusacuminata). Agronomía Costarricense. 2000;24(1):75-80.

11. Saldívar P, Laguna A, Gutiérrez F, et al. Gibberelic acid and seed germination of Jaltomata procumbens (Cav.) J. L. Gentry. Agronomía Mesoamericana. 2010;21(2):327-331. 